\title{
Climate induced changes in the circulation and dispersal patterns of the fluvial sources during late Quaternary in the middle Bengal Fan
}

\author{
OnKar S Chauhan ${ }^{1, *}$ and E Vogelsang ${ }^{2}$ \\ ${ }^{1}$ National Institute of Oceanography, Dona Paula, Goa 403 004, India. \\ ${ }^{2}$ Institut für Geowissenschaften, Universität Kiel, Olshausenstrasse 40, D - 24118 Kiel, Germany. \\ *e-mail: onkar@nio.org
}

From a transact along $15^{\circ} \mathrm{N}$ latitude in the middle Bengal Fan, temporal and spatial variations in the granulometric parameters and clay minerals in ${ }^{14} \mathrm{C}$ dated box cores from the eastern, the central and the western regions were studied to determine climate induced changes in the hydrography. Clay assemblages have spatial and temporal changes and are markedly different in the eastern and the western bay. From a high abundance of the clay smectite, which has its major source in the Deccan Basalt in peninsular India, it is inferred that the western bay is predominantly a depocenter of 'peninsular sources'. The eastern and the central regions of the bay, however, mostly receive sediments of the 'Himalayan source'. Related to unstable climate, the reported dominant illite-chlorite $(\mathrm{I}+\mathrm{C})$ assemblage in the eastern region of the bay $(\mathrm{I}+\mathrm{C}>60 \%$ smectite $<15 \%$ ), between 18 and $12.6 \mathrm{ka} \mathrm{BP}$, points to a predominant supply from the Himalayan sources through equatorwards dispersal by the winter hydrography. Higher smectite, and reduced clays of the Himalayan sources (smectite $>25 \%$; I $+\mathrm{C}>45 \%$ ) are reported also after $12.5 \mathrm{ka}$ BP from the eastern bay. These are interpreted as evidences of an intensified SW monsoon and associated change in the dispersal pattern by stronger summer monsoon hydrography which supports across bay dispersal by anticyclonic gyre. The influence of climate on hydrographic changes is consistent during the short events of arid climate (weak NE monsoon) in Holocene in core 31/1(western bay), in which the enhanced contents of the clays of the Himalayan sources are observed (smectite $<40 \%$ $\mathrm{I}+\mathrm{C}>50 \%$ ). These findings have implications for climate regulated influence of fluvial processes over the areas, hitherto, considered unaffected by the Indian peninsular fluvial sources.

\section{Introduction}

The Bay of Bengal is one of the largest terrigenous input sites of the world oceans. It receives, through fluvial influx, a large amount of land-released matter from the north (the Rivers Ganga-Brahmaputra), the west (the Mahanadi, the Godavari, the Krishna and the Cauvery Rivers) and the east (the Irrawady River), which contributes towards the growth of the Bengal Fan the largest of its kind in the world (Van der Borch et al 1974). The Bengal Fan extends for $3000 \mathrm{~km}$
$\mathrm{N}-\mathrm{S}$ and $1430 \mathrm{~km} \mathrm{E}-\mathrm{W}$ at $15^{\circ} \mathrm{N}$. Several valleys mark the surface of the fan in the central region of the bay, but presently only one is connected to 'Swatch of no ground' (Emmel and Curray 1984). The annual sediment discharge to the bay is about 2000 million ton from these prominent perennial rivers. Associated with the injection of fresh waters, the peak input of terrigenous flux into the bay, derived from the time series trap experiments, particularly from the Ganga-Brahmaputra rivers ( $\mathrm{G}-\mathrm{B}$; Ittekkot et al 1991), is during the SW monsoon. Due to the large fluvial influx, there is a

Keywords. Himalayan sources; Bengal Fan; hydrography; dispersal patterns; clay minerals. 


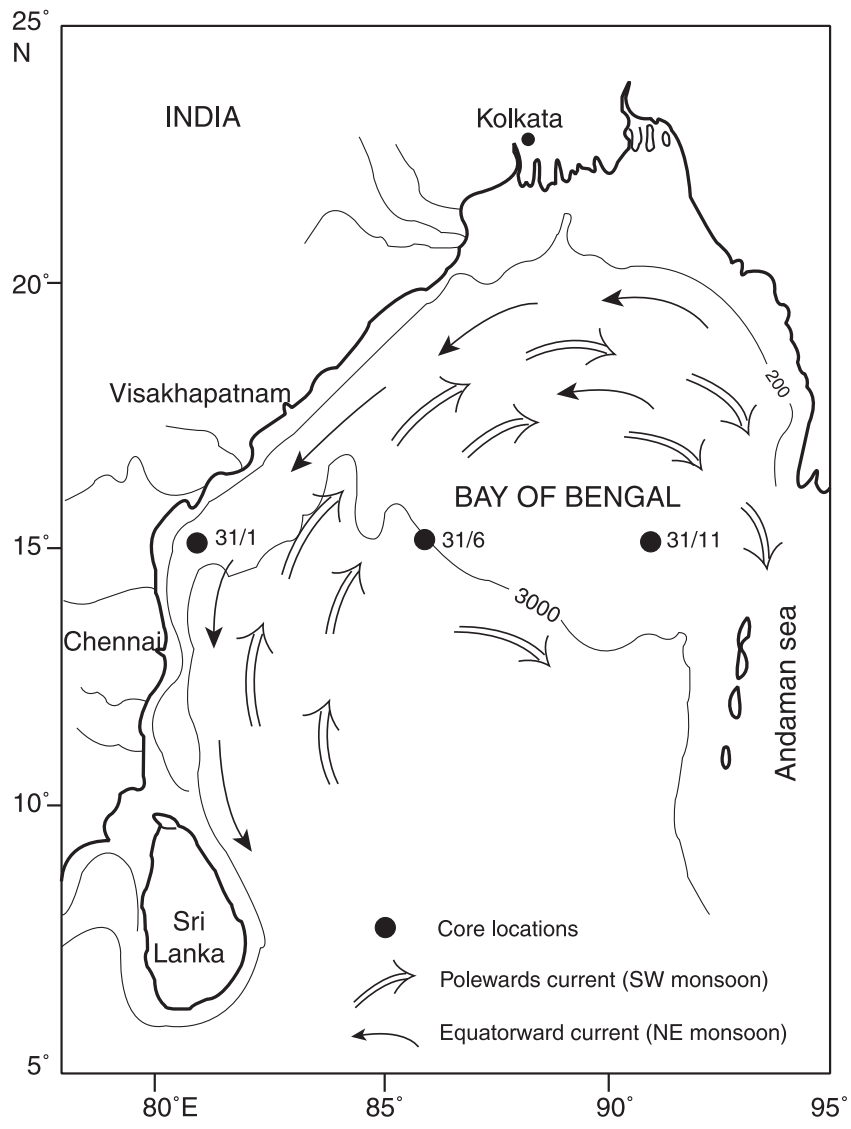

Figure 1. Prevalent regional hydrography (Shetye et al 1991, 1993; Verkey et al 1996) and core locations in the Bay of Bengal.

significant salinity reduction $(\sim 7 \%)$ in the northern bay (Levitius et al 1994). The plume of fresh water extends southwards up to $15^{\circ} \mathrm{N}$ latitude.

The bay has a complex hydrography governed by the reversal of winds associated with the monsoon phenomenon. The coastal circulation in the bay is mostly driven by the river runoff and hydrometeorological parameters (Varkey et al 1996). Regional, anticyclonic, poleward currents carry high salinity waters of the southern and the central regions across the bay during the southwest (SW) monsoon (June through September). There is also localized upwelling along the east coast of India during the SW monsoon. The current direction changes drastically over the pre- and post-monsoon periods with localized cells. Remotely controlled equatorwards, cyclonic gyre has been reported in the bay during the northeast (NE) winter monsoon (Varkey et al 1996). The currents are generally weak, equatorwards during most of the transitional period along the east coast of India (Shetye et al 1991, 1993; figure 1). It has been debated whether the intensity of the SW and the NE monsoons is interlinked, i.e., a stronger SW monsoon (summer monsoon) may lead to a weaker NE monsoon (Sarkar et al 1990). Based on the isotopic signature, however, Tiwari et al (2005), suggested a weak SW monsoon even though the NE monsoon was stronger during the late LGM. It implies that being climate dependent, the hydrography vis-à-vis dispersal pathways of the specific fluvial discharge may also have modified under different climate regimes of weak (stronger) NE (SW) monsoon.

Based upon the studies of the clays and the components of surficial sediments, fluvial sources predominantly contributing sediments into the different regions of the bay have been broadly determined (Kolla and Rao 1991). Because Tiwari et al (2005) have shown stronger equatorward currents during the late LGM, when the SW monsoon was weak, which implies that the hydrography of the bay varies with respect to NE and SW monsoons, studies of the surficial sediments alone are not entirely sufficient to understand the source to sink mechanism of specific fluvial sources vis-àvis climatic variability. The climate of the bay is known to have undergone century scale changes since LGM (Chauhan et al 1993, 2004; Weber et al 1997; Chauhan and Suneethi 2001; Kudrass et al 2001; Chauhan 2003). However, studies of temporal variations in the supply of terrigenous clays, under specific influence of climate vis-à-vis dispersal pathways of the sediments of these fluvial sources in the different regions of the bay are still in a state of infancy.

The clay minerals are $<2 \mu \mathrm{m}$ in size and have the potential to remain in suspension for long distances in the open ocean. The clay assemblages, being dependent upon hinterland geology, drainage and climate, are also source specific. Being carried mostly in the suspension, the clay minerals have the potential to be used to determine the dispersal pathways of a specific fluvial source. This study evaluates temporal variations in clay minerals and granulometric parameters in two ${ }^{14} \mathrm{C}$ dated cores retrieved from the middle fan region of the Bay of Bengal located in the area which predominantly receives sediments from the peninsular and the Himalayan rivers. Being one of the largest depocenters of terrigenous influx, most of the area of the bay is covered with a fan having altered sequence. In such a dynamic environment, due to the practical problem of obtaining a turbidity free core, and in the absence of availability of any other suitable turbidity free core, we have also used the published results of the clay analysis of Chauhan et al (2004) from the eastern region of the bay:

- to obtain a regional clay distribution in the middle fan region and

- to determine specifically dispersal pathways during the LGM, the period not covered by the other cores, for comparison with that of the Holocene. Emphasis is placed to understand the relation 
Table 1. Ages of the cores 31/1 and 31/6 (Chauhan et al 2001).

\begin{tabular}{|c|c|c|c|c|}
\hline Sl. no. & Laboratory no. & $\begin{array}{c}\text { Sample } \\
\text { interval }(\mathrm{cm})\end{array}$ & ${ }^{14} \mathrm{C}$ age & $\begin{array}{l}\text { Corrected } \\
{ }^{14} \mathrm{C} \text { age }\end{array}$ \\
\hline & Core $31 / 1$ & & & \\
\hline 1 & KL 31/1 01 & $6-8$ & $920+90$ & 520 \\
\hline 2 & KL 31/1 02 & $18-20$ & $1420+90$ & 1020 \\
\hline 3 & KL 31/1 03 & $28-30$ & $1720+90$ & 1320 \\
\hline 4 & KL 31/1 04 & $38-40$ & $2150+110$ & 1750 \\
\hline 5 & KL 31/1 05 & $46-48$ & $2650+100$ & 2250 \\
\hline 6 & KL 31/1 06 & $58-60$ & $2900+90$ & 2500 \\
\hline 7 & KL 31/1 07 & $68-70$ & $3550+110$ & 3150 \\
\hline 8 & KL 31/1 08 & $74-76$ & $4100+110$ & 3700 \\
\hline 9 & KL 31/1 09 & $82-84$ & $4200+100$ & 3800 \\
\hline 10 & KL 31/1 10 & $88-90$ & $4800+110$ & 4400 \\
\hline 11 & KL 31/1 11 & $118-120$ & $5600+120$ & 5200 \\
\hline 12 & KL 31/1 12 & $148-150$ & $6000+110$ & 5600 \\
\hline 13 & KL 31/1 13 & $158-160$ & $6200+100$ & 5800 \\
\hline 14 & KL 31/1 14 & $168-170$ & $6400+110$ & 6000 \\
\hline 15 & KL 31/1 15 & $178-180$ & $6790+110$ & 6390 \\
\hline 16 & KL 31/1 16 & $200-202$ & $7700+110$ & 7300 \\
\hline 17 & KL 31/1 17 & $213-215$ & $8550+110$ & 8150 \\
\hline 18 & KL 31/1 18 & $230-232$ & $9230+120$ & 8830 \\
\hline 19 & KL 31/1 19 & $250-252$ & $9500+140$ & 9100 \\
\hline 20 & KL 31/1 20 & $268-270$ & $9700+120$ & 9300 \\
\hline \multirow[t]{2}{*}{21} & KL 31/1 21 & 298-300 & $11400+160$ & 11000 \\
\hline & Core $31 / 6$ & & & \\
\hline 22 & KL $31 / 61$ & $20-25$ & $2560+100$ & 2160 \\
\hline 23 & KL $31 / 62$ & $40-45$ & $4630+150$ & 4230 \\
\hline 24 & KL $31 / 63$ & $50-55$ & $5260+130$ & 4860 \\
\hline 25 & KL $31 / 64$ & $60-65$ & $6200+150$ & 5800 \\
\hline 26 & $\mathrm{KL} / 31 / 65$ & 85-90 & $6500+130$ & 6100 \\
\hline 27 & $\mathrm{KL} / 31 / 66$ & $115-120$ & $6450+130$ & 6065 \\
\hline 28 & KL 31/6 7 & $185-190$ & $6400+130$ & 6000 \\
\hline
\end{tabular}

between the climate-induced changes in the hydrography and dispersal pathways of the fluvial clay influx under varied climatic conditions during the LGM (dominant NE monsoon) and the Holocene (intensified summer monsoon regime; Chauhan 2003; Chauhan and Suneethi 2001; Kudrass et al 2001).

Because the bay is a depocenter of multiple fluvial systems, core locations have to be chosen in the regions known to have influences of a specific source. For this purpose, the region across $15^{\circ} \mathrm{N}$ latitude is suitable because:

- in the eastern region, sea surface salinity (SSS) is influenced by fluvial influx of the G-B, while

- the western bay is a depocenter of major Indian peninsular rivers, the Godavari and the Krishna $(\mathrm{G}-\mathrm{K})$. Score of cores was collected during the 31st expedition of ORV Sagar Kanya from this region. Core $31 / 1$ (western core) lies off the mouths of the peninsular rivers $\left(15.00^{\circ} 20^{\prime \prime} \mathrm{N}\right.$; $81.49^{\prime \prime} \mathrm{E}$ water depth $2524 \mathrm{~m}$ ), in the regions reported to receive sediments from the peninsular region (Kolla and Rao 1991). The other core $(31 / 6)$ is located in the central regions $\left(14.59^{\circ} 68^{\prime \prime} \mathrm{N}\right.$; $86.5917^{\prime \prime} \mathrm{E}$ water depth $\left.2952 \mathrm{~m}\right)$ in the channel-levees system, and is chosen to determine the evidences and consistency of across bay dispersal, or lateral advection of sediments from the channels-levees to the eastern or to the western bay. Because of the nonavailability of any suitable turbidity free core from the eastern bay (strongly influenced by the influx of the Himalayan rivers G-B), for comparison of clay abundance with that of the western and the central regions of the bay, we have referred to the published century scale climate reconstruction and clay minerals and granulometric data of Chauhan et al (2004) (location $15.00^{\circ} .52^{\prime \prime} \mathrm{N} ; 91.10^{\prime \prime} \mathrm{E}$ water depth $\left.2713 \mathrm{~m}\right)$ to 
arrive at regional changes in the dispersal pathways of the clays from the peninsular and the Himalayan sources.

\section{Methodology}

The cores were subsampled at 2 and $5 \mathrm{~cm}$ (for core $31 / 6$ ) intervals. Salt free, oven dried, samples were subjected to the granulometric studies at $1 \varphi$ intervals following the methods of Folk (1966). The clay mineral analyses were undertaken on the oriented, carbonate and organic carbon free, $<2 \mu \mathrm{m}$ fractions. Clay minerals have been identified and quantified from the methods of Biscaye (1965). Based upon the replicate analysis the accuracy of the analysis is $\pm 5 \%$ for illite, chlorite and kaolinite and $\pm 8 \%$ for smectite. The cores have been bulk ${ }^{14} \mathrm{C}$ dated (28 levels, table 1; Chauhan et al 2001). In the absence of the apparent age of the waters of the bay, the carbonate ${ }^{14} \mathrm{C}$ dates have been corrected by $400 \mathrm{y}$ to nullify the reservoir effects (Stuiver and Reimer 1993) (table 1). Because these ages are correlated with that of Chauhan et al (2004), these are not converted into calendar ages in order to maintain uniformity.

\section{Results}

The texture of the sediments in cores is presented in figures $2(\mathrm{a})-3(\mathrm{a})$. The sediments in general, have a silty-clay to clayey-silt texture except in the core $31 / 6$, where the sediments have sandy-silt texture below $65 \mathrm{~cm}$ levels. The clays show significant temporal variations in the cores (figures $2 \mathrm{bc}-3 \mathrm{bc}$ ). Illite and chlorite are the dominant clays in the core $31 / 6$, but the western core $(31 / 1)$ has a higher content of smectite (figures 2-3). Smectite content in core $31 / 1$ varies between 66 and $17 \%$, and we have observed a specific reduction in its content at 285-275, 205-195, 165-94, 50-40 cm levels $(<42-17 \%$ in these sections; $>42 \%$ in the remaining core) corresponding to the time span of $10.1-9.6 \sim 7.3,5.8-4.3$ and $2.2-1.8 \mathrm{ka} \mathrm{BP}$ of assigned ages respectively. At these levels, illite and chlorite contents are generally high (figure 2). In core $31 / 6$, between 65 and $200 \mathrm{~cm}$ levels, the illite content is drastically increased $(>80 \%)$ and remains unchanged. Conspicuously, the other clays are present in trace quantities here. The core top $(0-15 \mathrm{~cm})$ has high smectite (range $30-51$; age $<1.5 \mathrm{ka} \mathrm{BP})$, though chlorite and illite are reduced here (figure 3 ).

The rates of sedimentation are different at both cores. The averaged rate of sedimentation in core $31 / 1$ is $27.27 \mathrm{~cm} \mathrm{ka}^{-1}$. The rate of sedimentation in the central core $31 / 6$ is highly variable. The ages

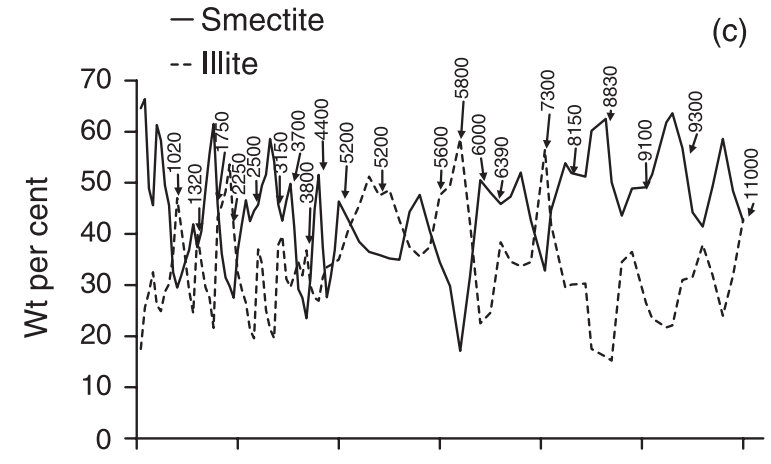

(c)
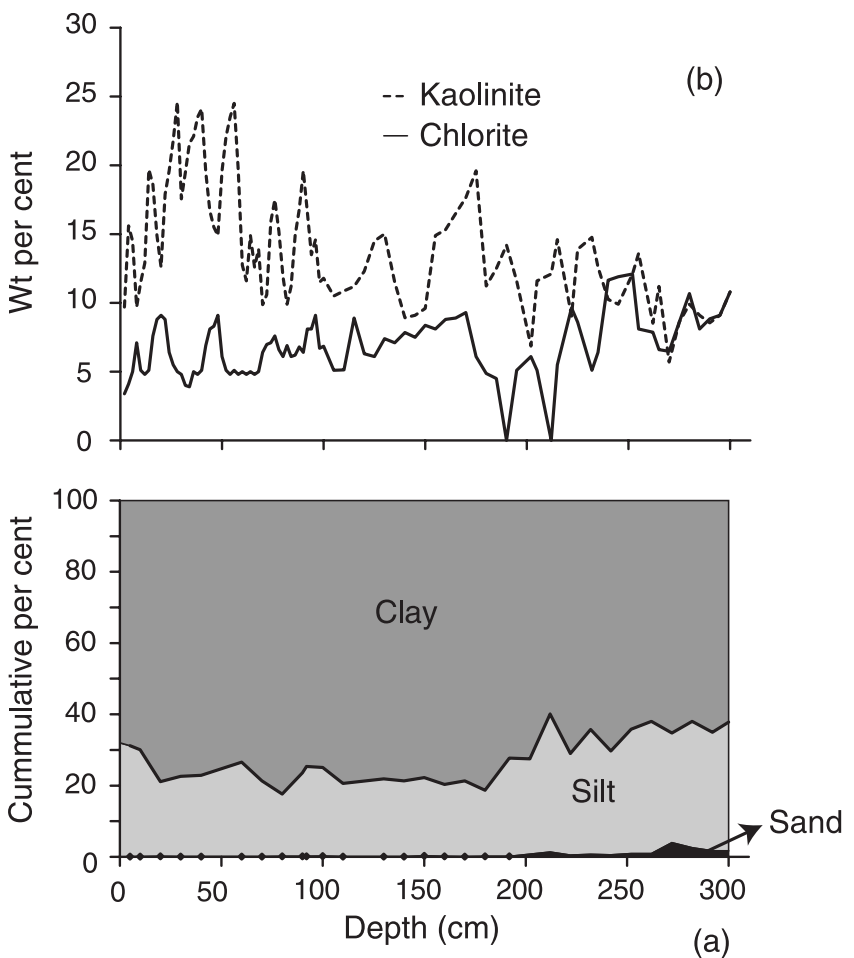

Figure 2. Temporal variations in granulometric parameters and clay minerals in core $31 / 1$. Corrected $14 \mathrm{C}$ ages are shown.

are uniform or reversed between 65 and $200 \mathrm{~cm}$ levels. Derived from the expected decreasing trend of ${ }^{14} \mathrm{C}$ dates with depth, the rate of the sedimentation is about $11.5 \mathrm{~cm} \mathrm{ka}^{-1}$ in upper $0-25 \mathrm{~cm}$ levels.

\section{Discussions}

Because the clays are the weathering product, and their production and liberation is dependent upon the geology, drainage and the prevalent climate (Weaver 1989) of a given region, the load of the Himalayan and the Indian peninsular rivers are markedly different. Konta (1985) and Subramanian (1987) have determined the clay loads of the Himalayan and the peninsular rivers respectively. These studies report illite + chlorite with minor kaolinite as dominant clays found in the load of the Himalayan rivers (Konta 1985; 

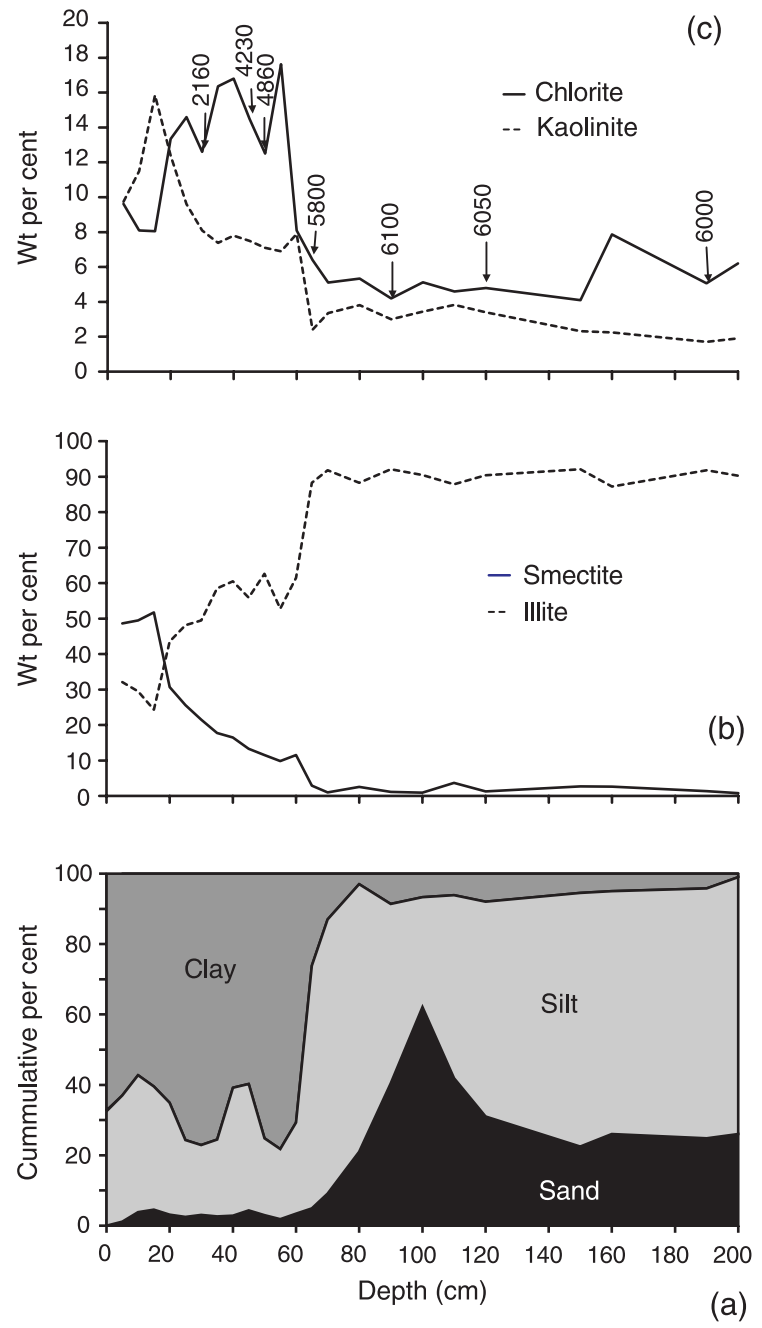

Figure 3. Same as figure 2, but for core $31 / 6$. From higher sand, uniform ages and higher illite it is inferred that 65-200 cm levels are deposited by a turbidity event.

Chauhan et al 2004). Smectite with minor kaolinite and traces of illite are reported in the load of the G-K system (Subramanian 1987). This is expected because the peninsular rivers have a major catchment area in the Deccan Basalt, which is the main source of smectite in this region. It may therefore be inferred that smectite is contributed mostly from the Indian peninsular rivers $\mathrm{G}-\mathrm{K}$. Chlorite is conspicuous by its absence in the loads of these peninsular rivers (Subramanian 1987). Therefore, the source of smectite, illite and chlorite can be tied to the specific fluvial sources. Being found in all the rivers, kaolinite has little application to determine dispersal pathways.

Emmel and Curray (1984) have suggested mass gravity processes in the entire middle bay due to fan building activity supported by the sediment supply through the canyon of the G-B system. We have observed an increasing trend of ${ }^{14} \mathrm{C}$ dates with depth in core 31/1 (figure 2), which suggests that the core is not influenced by turbidity induced

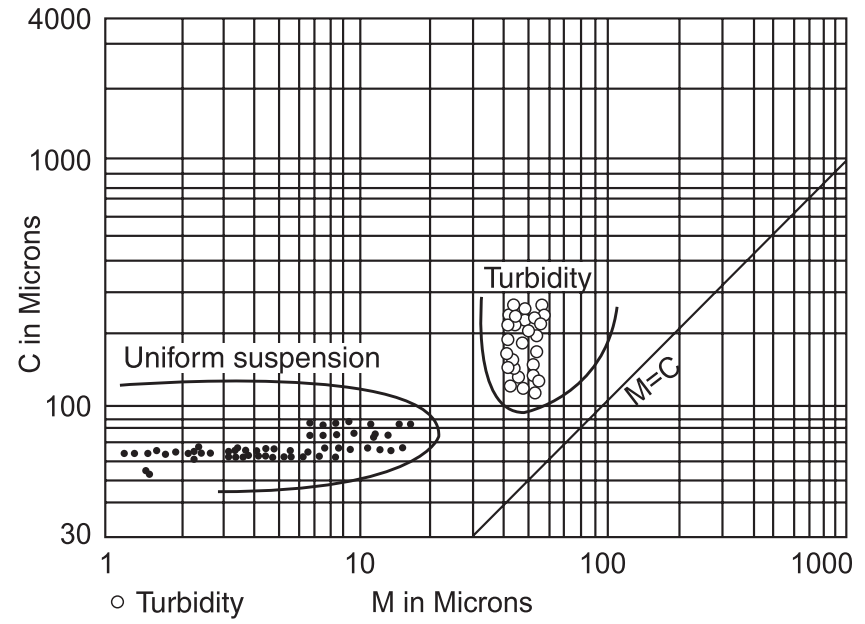

Figure 4. $\mathrm{C} / \mathrm{M}$ diagram for the cores. The sediments of core $31 / 6$ between 65 and $200 \mathrm{~cm}$ levels (open circles) distinctly fall in 'turbidity zone'. Closed circles for core $31 / 1$ and $0-65 \mathrm{~cm}$ levels of core $31 / 6$.

sedimentation, and can be used to reconstruct the temporal variations in the climate induced changes in the fluvial influx at the core site. Core $31 / 6$ from the central region, however, has reversal of the ages in the lower sections, and these levels appear to be influenced by the mass gravity processes. We have also plotted our data in $\mathrm{C} / \mathrm{M}$ diagram (Passega 1964) to further evaluate the mode of deposition at each core site (figure 4). The sediments of the western core $31 / 1$ occupy the region demarcated for 'uniform suspension'. This implies that most of the influx at this core site is through suspension, and gravity induced sedimentation is absent. However, the lower levels of the core $31 / 6$ (central bay) conspicuously fall in the 'turbidity domain' (not deposited from water column by uniform suspension), and further corroborates an altogether different mode of deposition due to the existence of turbidity induced sedimentation in the central bay prior to $5 \mathrm{ka} \mathrm{BP}$.

For comparison, we have evaluated the rate of sedimentation in the eastern bay from the available, published results of Chauhan et al (2004). The average rate of sedimentation is least here $\left(\sim 5 \mathrm{~cm} \mathrm{ka}^{-1}\right)$ compared to the western or central regions. Illite, chlorite, smectite and kaolinite in the order of abundance have been reported from this site. From rather low values in the entire LGM $(<13 \%)$, there is an increasing trend in the abundance of smectite during the Holocene $(>25 \%$; refer figure 2; Chauhan et al 2004). From the temporal variations in the abundance of the clay minerals in this study, it may be deduced that there are two distinct patterns during post- and pre-Holocene. Illite-chlorite dominated clay assemblage (I+C $>60 \%$; smectite $<13 \%$ ) is observed between 65 and $100 \mathrm{~cm}$ levels (age 12.6-18 ka BP; 

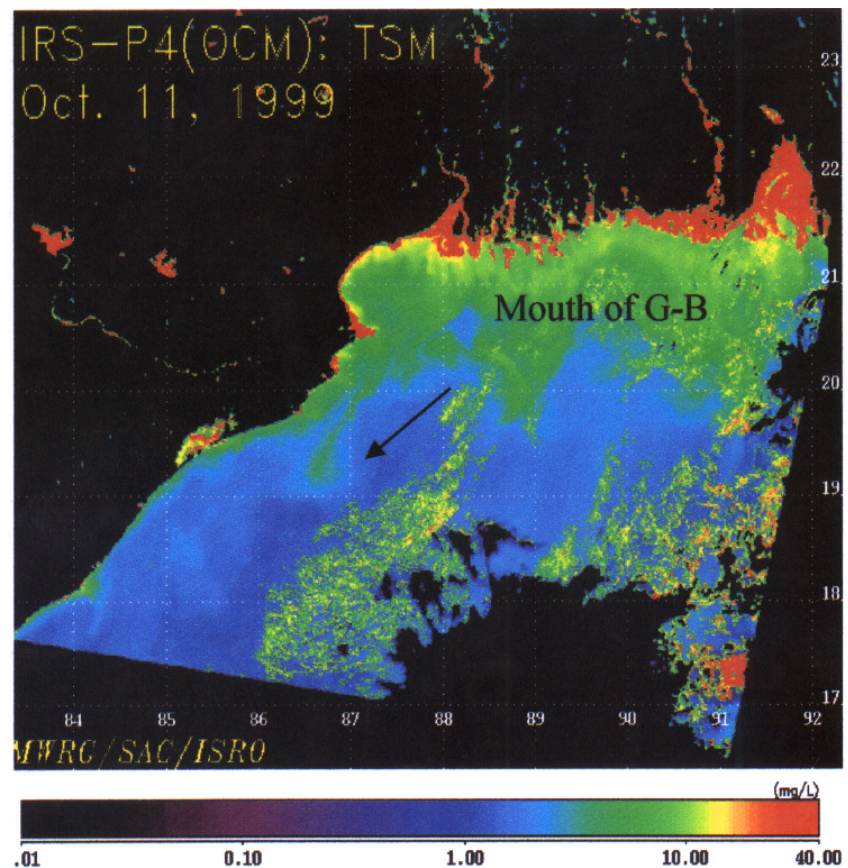

Figure 5. Geo-referenced, imagery of Indian Remote Sensing Satellite (IRS OCM P-4, 11 October, 1999) from the northern regions of the bay (modified from Chauhan et al 2005). Arrow shows equatorwards regional suspended matter dispersal during the NE monsoon (October-January) in the bay.

refer figure 2, Chauhan et al 2004), and it is inferred, therefore, that the eastern region prior to $12.5 \mathrm{ka} \mathrm{BP}$ was receiving sediments mainly from the Himalayan source. The climatic changes in the bay since last glaciations have been reconstructed in the earlier studies (Chauhan 2003; Chauhan et al 2004). The climate was arid between 18 and $15 \mathrm{ka} \mathrm{BP}$, and was unstable between 15 and $12.6 \mathrm{ka} \mathrm{BP}$ with rather low intensity of the SW monsoon (Chauhan et al 1993, 2004; Weber et al 1997; Chauhan and Suneethi 2001; Kudrass et al 2001; Chauhan 2003). The bay witnessed intensified monsoon after $12.6 \mathrm{ka} \mathrm{BP}$ (Weber et al 1997; Chauhan and Suneethi 2001), accompanied with two prominent phases of freshwater influx IA and IB around 11.5 and $9.5 \mathrm{ka}$ BP (Chauhan 2003; Chauhan et al 2004) respectively. As indicated earlier, Tiwari et al (2005) have reported that the SW monsoon was weak, though the NE monsoon hydrography was stronger during the LGM. This implies that the dispersal pathways were regulated by the NE monsoon hydrography prior to $12.5 \mathrm{ka} \mathrm{BP}$, when the $\mathrm{SW}$ monsoon was weak. During the NE monsoon (prevalent from October through January), reported hydrography is equatorwards (Shetye et al 1991, 1993). We have evaluated imageries of the Indian Ocean Satellite, Ocean Color Monitor (P-4) from the northern Bay of Bengal to determine regional dispersal pathways of the suspended matter during the NE monsoon (Chauhan et al 2005), which is equatorwards during October 1999 (figure 5), and further supports our thesis of southward advection of the discharge of the $\mathrm{G}-\mathrm{B}$ and the $\mathrm{K}-\mathrm{G}$ by the winter hydrography. Being climate dependent, it implies that the polewards hydrography of the SW monsoon was rather weak prior to $12.5 \mathrm{ka} \mathrm{BP}$, and the clays were mostly dispersed by the equatorwards winter currents as observed in the satellite imageries.

The climate reversal after $12.5 \mathrm{ka} \mathrm{BP}$ appears to have modified the hydrography. Because during the SW monsoon hydrography is polewards, anticyclonic gyre (Shetye et al 1991, 1993), it will support advection and dispersal of the suspended flux of the peninsular sources into the eastern bay. There is a consistent increasing trend in the content of smectite after $12.5 \mathrm{ka}$ BP $(<13 \%$ and $>25 \%$ in preand post- $12.5 \mathrm{ka} \mathrm{BP}$ sections respectively). Higher smectite in the entire Holocene section of the eastern region $(>25 \%$; Chauhan et al 2004) may therefore be interpreted as an evidence of major changes in dispersal pathways of the peninsular sources due to modified hydrographic regime, i.e., an initiation of stronger across-shelf dispersal by poleward currents which appear to have sustained with minor fluctuations during the Holocene.

In the central bay (core $31 / 6$ ), however, two distinct environments of deposition have been observed. Between 65 and $200 \mathrm{~cm}$ levels in core $31 / 6$, the sediment texture is uniformly silty-sand. In the $\mathrm{C} / \mathrm{M}$ diagrams (Passega 1964), the sediments of these levels occupy the 'turbidity'; and not the 'suspension' domain as has been the case for the sediments of core 31/1 (figure 4). These levels also have uniform or altered ${ }^{14} \mathrm{C}$ age ranging between 5.8 and $6 \mathrm{ka} \mathrm{BP}$, and we therefore demarcate these as turbidity events in the central bay. Illite is the major clay ( $>80$ per cent), and its contents are more or less constant at all these levels of the core (figure 3). The uniformity in contents of all the clays, together with similar or reversed ages here, leads us to designate this entire section as one litho-unit deposited by a turbidity pulse. Due to emplacement of this turbidity, it is not possible to reconstruct the sources of the sediments in the central bay prior to the mid-Holocene. However, from the content of high illite in this entire turbid section $(>80 \%)$, it may be inferred that this turbidity pulse is related to the Himalayan rivers. The signature of this turbidity pulse is not observed in other cores. The sediments of this litho-unit are dominated by the sand fraction, which cannot be transported in the suspension for long distances. Therefore, it is deduced that this episodic turbidity pulse in the middle fan regions was rather local.

The upper surfaces $(0-60 \mathrm{~cm}$ age $<4.8 \mathrm{ka} \mathrm{BP})$ of the core $31 / 6$, however, have significant contents 
of illite and chlorite, which are the constituents of fluvial sources of the Himalayan rivers. Smectite is also conspicuously increased in the upper section only (levels $0-15 \mathrm{~cm}, 30-51 \%$ ), and the deduced mode of deposition is 'suspension' here (figure 4). Ages at these levels are also sequential without any reversal (figure 3). From the assemblage of the clays, particularly from the increasing trend of smectite $(30-51 \%)$, it is inferred that this location is receiving clay flux from two distinct sources, i.e., illite and chlorite from the $\mathrm{G}-\mathrm{B}$ and smectite from the peninsular sources. The occurrence of high smectite during the late Holocene $(<1.5$ ka BP; content $>45 \%)$ provides further evidence of a larger influence of the peninsular rivers on the central regions of the bay, which was, hitherto, considered a depocenter of the G-B system (Emmel and Curray 1984; Kolla and Rao 1991). An average rate of sedimentation is $\sim 11 \mathrm{~cm} \mathrm{ka}^{-1}$ in the central bay, which is much higher than observed in the eastern region (Chauhan et al 2004), even though these core sites have almost similar distance from the mouth of the $\mathrm{G}-\mathrm{B}$. The enhanced rate of sedimentation at the central bay may be attributed to the supply from the Himalayas as well as peninsular sources.

Smectite is the major clay observed in core $31 / 1$ (range 67-21\%; figure 2). Besides, illite (range 19-58\%), kaolinite (range 6-24), and chlorite (traces $-8 \%$ ) are observed in the order of abundance. This location lies off the mouth of the peninsular rivers $\mathrm{G}-\mathrm{K}$. A higher smectite in the core, therefore, appears to be related to proximity to the peninsular sources. From the occurrence of illite and chlorite, it is also inferred that even though the main source of terrigenous flux is from the peninsular rivers, the western bay also receives sediments of the G-B system by equatorwards dispersal. The overall rate of sedimentation in the core is $\sim 27 \mathrm{~cm} \mathrm{ka}^{-1}$, which appears to be related to:

- proximity of the core site to the peninsular rivers, and

- being the depositional site receiving sediments from multiple sources.

Being depocenter of peninsular as well as Himalayan rivers, this site is expected to archive temporal variations in the intensity of cyclonic gyre prevalent during the NE monsoon carrying the sediment of the Himalayan rivers. We have observed specific variations in the content of smectite, illite and chlorite in this core at 285-275, 205-195, 16594 , and $50-40 \mathrm{~cm}$ levels corresponding to a timespan of 10.1-9.6, 7.3, 5.8-4.3 and $2.2-1.8 \mathrm{ka} \mathrm{BP}$ respectively. The reduction in smectite with corresponding increase in the contents of $\mathrm{I}+\mathrm{C}$ at all these levels have been observed and evaluated with reported climate at these times to elaborate the influence of climate on dispersal pathways. There are documentations of pauses in the intensity of the SW monsoon during the Holocene at all these times (Sirocko et al 1993; Kudrass et al 2001; Agnihotri et al 2002; Chauhan 2003; Chauhan et al 2004). First of these events is specifically coeval with the 'Younger Dryas' event in the world climate model with an intensified NE monsoon regime (Kudrass et al 2001; Chauhan 2003). An overall reduced influx of smectite during all these known events of aridity, therefore, further supports the influence of climate on the hydrographic changes and dispersal pathways.

It may, therefore, be summarized that the sources and dispersal of the sediments in the bay have been significantly regulated by climate changes. Concurrent with the prevalent climate, winter hydrography has played a more dominant role in dispersing the sediments prior to $12.5 \mathrm{ka} \mathrm{BP}$, when the winter monsoon hydrography was dominant.

With initiation of stronger summer monsoon regime at $12.5 \mathrm{ka} \mathrm{BP}$, the bay has witnessed a change in the dispersal pattern, i.e., a higher magnitude of polewards, across-shelf dispersal during the entire Holocene. In the central bay, characterized by channel-levees, sedimentation is also influenced by localized, episodic turbidity pulse fed from the Himalayan sources.

\section{Acknowledgements}

Authors are thankful to the Director, National Institute of Oceanography, Goa for providing the facilities. Thanks are also due to Prof. S Krishnaswami and Rajesh Agnihotry for constructive and useful comments. We thank G Prabhu and Madhavi Talualikar for help with $\mathrm{X}$-rd analysis and manuscript preparation. This is the contribution no 4084 of NIO, Goa.

\section{References}

Agnihotri R, Dutta K, Bhushan R and Somayajulu BLK 2002 Evidence for solar forcing on Indian monsoon during the last millennium; Earth Planet. Sci. Lett. 198 521-527.

Biscaye P E 1965 Mineralogy and sedimentation of recent deep-sea clays in the Atlantic Ocean and adjacent seas and oceans; Bull. Geol. Soc. America 76 803-832.

Chauhan O S 2003 Past 20,000-year history of Himalayan aridity: Evidenced from oxygen isotope records in the Bay of Bengal; Curr. Sci. 84 90-93.

Chauhan O S, Borole D V, Gujar A R, Antonio M, Mislanker P G and Rao Ch M 1993 Evidences of climatic variations during Late Pleistocene-Holocene in the eastern Bay of Bengal; Curr. Sci. 65(7) 558-562.

Chauhan O S, Patil S K and Suneethi J 2004 Fluvial influx and weathering history of the Himalayas since 
Last Glacial Maxima; isotopic, sedimentological and magnetic records from the Bay of Bengal; Curr. Sci. 87(4) 509-515.

Chauhan O S, Rajawat A S, Pradhan Y, Suneethi J and Nayak S R 2005 Weekly observations on dispersal and sink pathways of the terrigenous flux of the GangaBrahmaputra in the Bay of Bengal during NE monsoon; Deep-Sea Res; Part II, 52 2018-2030.

Chauhan O S, Suneethi J and Sukhija B S 2001 Sedimentary environments in the middle Bengal Fan during Late Quaternary; Spec. Publ. GSI 65(III) 279-282.

Chauhan O S and Suneethi J $200118 \mathrm{ka}$ BP records of climatic changes, Bay of Bengal: Isotopic and sedimentological evidences; Curr. Sci. 81 1231-1234.

Emmel F J and Curray J R 1984 The Bengal submarine Fan, Northeastern Indian Ocean; Geo-Mar. Lett. 3 119-124.

Folk R L 1966 A review of grain size parameters; Sedimentology 6 73-98.

Ittekkot V, Nair R R, Honjo S, Ramaswamy V, Bartsch M, Mangani S and Desai B N 1991 Enhanced particle flux in Bay of Bengal induced by injection of fresh water; Nature 351 385-387.

Kolla V and Rao N M 1991 Sedimentary sources in surface and near surface sediments of the Bay of Bengal; GeoMar. Lett. 10 125-136.

Konta J 1985 In: Mineralogy and chemical maturity of suspended matter in major river samples under SCOPE/UNEP, Transport of carbon and minerals in major world rivers; Part III; (eds) Degens $\mathrm{T}$ and Kempe S, Mitteilungen aus dem Geologisch - Paleontologischen Institut der Universitat Hamburg, pp. 569.

Kudrass H R, Hofmann A, Doose H, Emeis $\mathrm{K}$ and Erlenkeuser H 2001 Modulation and amplification of climate changes in Northern Hemisphere by Indian summer monsoon during the past $80 \mathrm{Ky}$; Geology 29 63-66.

Levitius S, Burgett R and Boyer T P 1994 In: World Ocean Atlas: Salinity NOAA Atlas NESDIS 3; US Department of Commerce, Washington DC, Vol. 3.
Passega R 1964 Grain size representation by CM pattern as a geological tool; J. Sedim Geol. 34 830-847.

Sarkar A, Ramesh R, Bhattacharya S K and Rajagopalan G 1990 Oxygen isotope evidence for a stronger winter monsoon current during the last glaciation; Nature $\mathbf{3 4 3}$ $549-551$.

Shetye S R, Gouveia A, Shenoi S S C, Sundar D, Michael G S and Nampoothri G 1993 The western boundary current in the seasonal subtropical gyre in the Bay of Bengal; J. Geophys. Res. 98 945-954.

Shetye S R, Shenoi S S C, Gouveia A D, Michael G S, Sundar D and Nampoothri G 1991 Wind driven coastal upwelling along the western boundary of the Bay of Bengal during southwest monsoon; Continent. Shelf Res. 11 1397-1408.

Sirocko F, Sarnthein M, Erlenkeuser E, Lange H, Arnold M and Duplessy J C 1993 Century-scale events in monsoonal climate over the past 20000 years; Nature $\mathbf{3 6 4} 322-324$.

Stuiver M and Reimer P J 1993 Extended ${ }^{14} \mathrm{C}$ data base and revised calibration $3.0{ }^{14} \mathrm{C}$ age calibration program; Radiocarbon 35 215-230.

Subramanian V 1987 Environmental geochemistry of Indian rivers; J. Geol. Soc. India 29 205-220.

Tiwari M, Ramesh R, Somayajulu B L K, Jull A J T and Burr G S 2005 Early degalcial ( 19-17 ka) strengthening of northeast monsoon; Geophys. Res. Lett. 32 L19712.

Van der Borch C C, Sclater J G and others 1974 Site 218 initial report deep sea drilling project, (Washington DC: Govt. Printing Office) 22 325-348.

Varkey M J, Murthy V S N and Suryanarayana A 1996 Physical oceanography of the Bay of Bengal and Andaman Sea; Oceanography and Mar. Bio. 34 1-70.

Weaver C E 1989 Clays, Muds and Shales; (Amsterdam: Elsevier) p. 819.

Weber M E, Wiedicke H M, Kudrass H R, Hubscher C and Erlenkeuser H 1997 Active growth of the Bengal Fan during sea level rise and highstand; Geology $\mathbf{2 5}$ $315-318$ 